\title{
High resolution simulation of recent Arctic and Antarctic stratospheric chemical ozone loss compared to observations
}

\author{
Om Prakash Tripathi · Sophie Godin-Beekmann • \\ Franck Lefèvre · Marion Marchand • Andrea Pazmiño • \\ Alain Hauchecorne · Florence Goutail • Hans Schlager • \\ C. Michael Volk • B. Johnson • G. König-Langlo • \\ Stefano Balestri - Fred Stroh - T. P. Bui · H. J. Jost • \\ T. Deshler $\cdot$ Peter von der Gathen
}

Received: 30 June 2005 / Accepted: 6 April 2006 / Published online: 26 September 2006

(C) Springer Science + Business Media B.V. 2006

O. P. Tripathi · S. Godin-Beekmann · F. Lefèvre - M. Marchand · A. Pazmiño · A. Hauchecorne · F. Goutail

Service d'Aéronomie - IPSL du CNRS, Université Pierre et Marie Curie, 75252 Paris Cedex 05 France

H. Schlager

Institute for Atmospheric Physics, DLR, Oberpfaffenhofen, Germany

C. M. Volk

Institut für Atmosphäre und Umwelt, J.W. Goethe-Universität Frankfurt, Germany

B. Johnson

Climate Monitoring and Diagnostics Laboratory, National Oceanic and Atmospheric Administration, Boulder, Colorado 80305, USA

G. König-Langlo

Alfred Wegener Institute for Polar and Marine Research, Postfach 120161, D-27515 Bremerhaven, Germany

S. Balestri

Environmental Research \& Services, Sesto Fiorentino, Italy

F. Stroh

Institute for Chemistry and Dynamics of the Geosphere (ICG-I), Forschungszentrum Juelich GmbH, 52425 Juelich, Germany

T. P. Bui

NASA Ames Research Center, Moffet Field, CA, USA

H. J. Jost

Bay Area Environmental Reserach Institute, Sonoma, CA, USA

T. Deshler

Department of Atmospheric Science, University of Wyoming, Laramie, Wyoming, USA 
Abstract Simulations of polar ozone losses were performed using the three-dimensional high-resolution $\left(1^{\circ} \times 1^{\circ}\right)$ chemical transport model MIMOSA-CHIM. Three Arctic winters 1999-2000, 2001-2002, 2002-2003 and three Antarctic winters 2001, 2002, and 2003 were considered for the study. The cumulative ozone loss in the Arctic winter 2002-2003 reached around $35 \%$ at $475 \mathrm{~K}$ inside the vortex, as compared to more than 60\% in 1999-2000. During 1999-2000, denitrification induces a maximum of about $23 \%$ extra ozone loss at $475 \mathrm{~K}$ as compared to $17 \%$ in 2002-2003. Unlike these two colder Arctic winters, the 2001-2002 Arctic was warmer and did not experience much ozone loss. Sensitivity tests showed that the chosen resolution of $1^{\circ} \times 1^{\circ}$ provides a better evaluation of ozone loss at the edge of the polar vortex in high solar zenith angle conditions. The simulation results for ozone, $\mathrm{ClO}, \mathrm{HNO}_{3}$, $\mathrm{N}_{2} \mathrm{O}$, and $\mathrm{NO}_{y}$ for winters 1999-2000 and 2002-2003 were compared with measurements on board ER-2 and Geophysica aircraft respectively. Sensitivity tests showed that increasing heating rates calculated by the model by $50 \%$ and doubling the PSC (Polar Stratospheric Clouds) particle density (from $5 \times 10^{-3}$ to $10^{-2} \mathrm{~cm}^{-3}$ ) refines the agreement with in situ ozone, $\mathrm{N}_{2} \mathrm{O}$ and $\mathrm{NO}_{y}$ levels. In this configuration, simulated $\mathrm{ClO}$ levels are increased and are in better agreement with observations in January but are overestimated by about $20 \%$ in March. The use of the Burkholder et al. (1990) $\mathrm{Cl}_{2} \mathrm{O}_{2}$ absorption cross-sections slightly increases further $\mathrm{ClO}$ levels especially in high solar zenith angle conditions. Comparisons of the modelled ozone values with ozonesonde measurement in the Antarctic winter 2003 and with Polar Ozone and Aerosol Measurement III (POAM III) measurements in the Antarctic winters 2001 and 2002, shows that the simulations underestimate the ozone loss rate at the end of the ozone destruction period. A slightly better agreement is obtained with the use of Burkholder et al. (1990) $\mathrm{Cl}_{2} \mathrm{O}_{2}$ absorption cross-sections.

Keywords Comparison with observations $\cdot$ High-resolution 3-D chemical transport model $\cdot$ Ozone loss $\cdot$ Stratospheric chemistry $\cdot$ Polar ozone $\cdot$ Sensitivity tests

\section{Introduction}

During the last decade, many experimental evidences have confirmed substantial winter/spring Arctic lower stratospheric ozone depletion (Schoeberl et al., 1990; Kyro et al., 1992; Waters et al., 1993; Salawitch et al., 1993; Braathen et al., 1994; Rex et al., 1995; Bojkov et al., 1995; Manney et al., 1996; Hansen et al., 1997). Unlike in Antarctica where the ozone depletion in winter/spring is a regular feature, the inter-annual variability of temperature and consequently the ozone depletion in the Arctic stratosphere is very large. In recent Arctic winters e.g. 1999-2000 and 2002-2003, a sufficiently low temperature and consequently extensive formation of polar stratospheric clouds led to the long persistence of active chlorine species. Added to this was extensive de-nitrification (Fahey et al., 2001; Schiller et al., 2002) by the sedimentation of large PSC particles resulting in substantial winter/spring ozone depletion in the Arctic lower stratosphere. The 1999-2000 Arctic stratosphere was

P. von der Gathen

Alfred Wegener Institute for Polar and Marine Research, Research Department Potsdam, Telegrafenberg A43, Germany

O. P. Tripathi $(\varangle)$

NASA - Jet Propulsion Laboratory, California Institute of Technology, Table Mountain Facility, 24490

Table Mountain Road, P.O. Box: 367, Wrightwood, CA 92397, USA

e-mail: ompraka@aero.jussieu.fr, tripathi@tmf.jpl.nasa.gov

至Springer 
considered amongst the coldest one when the lower stratospheric temperature was below $195 \mathrm{~K}$ (required for PSC formation) for a large number of days (Manney and Sabutis, 2000). A coordinated campaign THESEO/SOLVE 2000 was carried out for the measurements of ozone and other species (Newmann et al., 2002). These observations were used to calculate chemical ozone depletion and provided an excellent platform to understand the ozone loss phenomenon. Extensive modeling studies including 3-D CTM and photochemical box models have been performed to observe chemical ozone loss particularly during 1999-2000 Arctic winter. Sinnhuber et al. (2002) found more than 2.5 ppmv (70\%) of chemical ozone loss from SLIMCAT at the end of March 2000, which was in good agreement with the ozonesonde observation at Ny-Ålesund. This much of ozone loss was however found to be due to cold bias in UKMO temperature. When the model was run with ECMWF temperature field, which were closer to the observations, chemical ozone loss was less than that calculated by Sinnhuber et al. (2002), despite a better agreement between modelled active chlorine and ER-2 observations. Kopp et al. (2002) compared KASIMA chemical transport model simulations using ECMWF analysis with the ozone observations by a Fourier transform infrared (FTIR) spectrometer and millimeter wave radiometer for 1999-2000 Arctic winter and found that the model underestimated these observations by $30 \%$ and $20 \%$ respectively. The modeling study of Pierce et al. (2002) shows a good agreement with ozone loss rates calculated from the Match analysis but at the cost of over prediction of chlorine activation. Using Chemical Lagrangian model of the Stratosphere (CLaMS) Groo $\beta$ et al. (2002) showed up to $60 \%$ of ozone loss between 425 and $450 \mathrm{~K}$ during mid-March, a good agreement with observation, but they define their denitrification on the basis of observed $\mathrm{NO}_{y}-\mathrm{N}_{2} \mathrm{O}$ relation and ER-2 temperature measurement. From these studies, it is clear that depending upon the model, adopted chemical and micro-physical scheme of PSC formation, growth and sedimentation, models have some deficiency to reproduce correct ozone loss. If they could, however, reproduce ozone loss correctly, it is due either to bias in temperature or over prediction of chlorine or using observed denitrification. One of the major issues in the current Arctic ozone loss modeling is to reproduce January ozone loss correctly (Rex et al., 2003), which can affect the overall ozone loss at the end of March. Due to unexplained ozone loss at high solar zenith angle (during January) a large uncertainty in overall modelled ozone loss was found for the winters like 1994-1995 and 1999-2000 when January ozone loss was larger in comparison to other winters (WMO, 2002). Another important issue is the implementation of the micro-physical scheme of the sedimentation of PSC particles to reproduce observed levels of de-nitrification. Various modeling studies (Drdla et al., 2002; Davies et al., 2002) have shown that the observed level of denitrification in the Arctic winters is not due to the sedimentation of synoptic scale ice clouds carrying nitric acid. It has now been accepted that the Arctic winter denitrification is most likely caused by the sedimentation of large nitric acid particles (Carslaw et al., 2002; Drdla et al., 2002; Davies et al., 2002). Current models generally use equilibrium scheme with either a fixed number density or size and number concentration from the observations. Davies et al. (2002) used sizes and number density of the observation by Fahey et al. (2001) and found the denitrification similar to that observed in the Arctic winter 1999-2000. But for better representation of denitrification in the model, the understanding of NAT particle formation mechanism, growth process, size, and number density are essential.

In Antarctica, a large wave activity followed by the splitting of Antarctic vortex has been observed in September 2002. A major stratospheric warming occurred due to extremely large heat flux at $100 \mathrm{hPa}$. The transport process during this major warming event caused a large column ozone anomaly and resulted in less mean vortex ozone loss in comparison to other Antarctic winters. Extensive observational and modeling studies performed for this winter 
showed the exceptional phenomenon and raised the speculation of its future likelihood in southern hemisphere (Allen et al., 2003; Hoppel et al., 2003).

In this paper we give an overview of the performance of the 3-D chemical transport model MIMOSA-CHIM against observations and other contemporary modeling studies for Arctic winters 1999-2000, 2001-2002, and 2002-2003 and the Antarctic winters 2001, 2002, and 2003. This model was used within the framework of the European project QUOBI (Quantitative Understanding of Ozone loss by Bipolar Investigation). The purpose of this project is to assess our understanding of the polar ozone loss mechanism and how correctly they are represented in current models. To that objective, the project is based on the use of various observational approaches including Match and several chemical transport models (CTM) and box models. Within QUOBI, we have tested the ability of MIMOSA-CHIM to reproduce polar ozone loss in both hemispheres. The model has been used in the past to evaluate the impact of polar ozone loss on mid-latitudes (Marchand et al., 2003) and comparisons have been made with ozonesonde observations at various stations. Here, we present extensive comparison with other minor species observed within the polar vortex. First we present a short introduction of the model and description of methods used in various calculations. Then the significance of the high horizontal resolution in the calculation of ozone loss, considering the Arctic winter 1999-2000 as a particular case, is discussed. We then compare model results for Arctic winter/spring 1999-2000 with the observations performed on the ER-2 aircraft during THESEO/SOLVE 2000 mission, EUPLEX (European Polar Stratospheric Cloud and Lee Wave Experiment) dataset and ozonesonde observations for the Arctic 2002-2003. In the last section we compare the ozonesonde and POAM III observations in the Antarctic winters 2001, 2002 and 2003. To compare our results with observations, several sensitivity tests were performed which are described in the following sections.

\section{Model description}

MIMOSA-CHIM, a chemical transport model, includes the PV advection model MIMOSA (Hauchecorne et al., 2002) and the chemistry scheme of the REPROBUS (Reactive Processes Ruling the Ozone Budget in the Stratosphere) (Lefèvre et al., 1994; Marchand et al., 2003). The model runs on an isentropic surface, starting on an orthogonal grid in an azimuthal equidistant projection centered at pole. The PV advection model starts from the meteorological PV field interpolated on the MIMOSA grid. The PV field is calculated from the meteorological pressure and temperature fields from ECMWF analyses and then interpolated to the MIMOSA grid. The PV of each grid point is advected using meteorological winds interpolated on the MIMOSA grid at the specified isentropic level. As the time passes the orthogonal MIMOSA grid is stretched and deformed by horizontal gradients in the wind field. After a given time $(6 \mathrm{~h})$ the PV field is re-interpolated to the original grid in order to keep the distance between two adjacent points approximately constant. For the time interval of six hours the average change in distance ranges from $10 \%$ to $15 \%$ in the region between 400 and $675 \mathrm{~K}$ potential temperature. The regridding process produces numerical diffusion and to minimize this diffusion, an interpolation scheme, based on the preservation of second order momentum of PV perturbation, has been implemented (Hauchecorne et al., 2002). The model was used to interpret observed ozone laminae in lidar profiles at Observatoire de Haute-Provence (OHP, 44 N, 5.7 E) and to support the planning of an air-borne ozone lidar on board of French Falcon (Mystere 20) (Hauchecorne et al., 2002; Heese et al., 2001). The model was successfully used to predict the development of a large filament and then detected by OHP lidar at $445 \mathrm{~K}$ (Godin et al., 2002).

氖 Springer 
The chemical fields of the MIMOSA-CHIM model are initialized by the 3-D CTM REPROBUS output fields interpolated on isentropic levels and are advected along with PV with a time step of one hour. PV is assumed to be conserved for up to two weeks on isentropic surfaces in the lower stratosphere. For longer simulations, the diabatic transport of air across isentropic surfaces, as well as the diabatic evolution of PV, have to be taken into account. Diabatic mass fluxes are computed from the heating rates calculated using the radiation scheme of the SLIMCAT model taken from MIDRAD (Chipperfield et al., 1999). Climatological water vapour, $\mathrm{CO}_{2}$ and interactive ozone fields (taken from the model itself) are used for the calculation of heating rates. The MIMOSA PV field is relaxed towards the ECMWF PV field with a time constant of 10 days. MIMOSA PV fields are smoothed to the same resolution as ECMWF fields and the difference between the two fields is used to compute the relaxation term.

Isentropic vertical coordinate is used in the model with sixteen levels from $350 \mathrm{~K}$ and $950 \mathrm{~K}$, yielding a vertical resolution of about $1.5 \mathrm{~km}$ in region below $500 \mathrm{~K}$ and a little more (between 1.5 to $2 \mathrm{~km}$ ) in the region above $500 \mathrm{~K}$. The horizontal resolution of the model is $1^{\circ}$ in latitude and longitude. In the present version, the model domain is centered at the pole and extends up to 60 degrees of latitude i.e. the latitude range of the simulation is $30^{\circ} \mathrm{N}(\mathrm{S})-$ $90^{\circ} \mathrm{N}$ (S) for Arctic (Antarctic) simulations. To take into account the influence of air masses originating from regions outside of the model domain, PV fields of ECMWF and chemical fields of REPROBUS are used for the forcing at the boundary of the model. The complete REPROBUS fields are generally available once a month, so they are interpolated in time for the forcing at the boundary. Sensitivity studies have shown that there is negligible effect of forcing, either using actual REPROBUS data or even climatological fields, on the ozone loss inside the vortex.

The model includes the chemical scheme of REPROBUS. This scheme includes 55 chemical species and calculates about 160 reactions including gas phase, heterogeneous, and photolytic reactions (Lefèvre et al., 1994, 1998). The REPROBUS value of $\mathrm{BrO}_{x}$ is based on a correlation with $\mathrm{CFC}-11$ that considered supply of bromine from $\mathrm{CH}_{3} \mathrm{Br}$, halons, as well as $\mathrm{CH}_{2} \mathrm{Br}_{2}$ and $\mathrm{CH}_{2} \mathrm{BrCl}$ [Wamsley et al., 1998]. The updates of JPL-2003 recommendations are implemented that made the changes in the rates of the reactions shown in Annex 1.

The model has a detailed scheme of PSC formation and growth. The saturation vapour pressure given by Hanson and Mauersberger (1988) is used to assume the existence of NAT particles and Murray (1967) for water-ice particle. A denitrification scheme is introduced to account for the sedimentation of $\mathrm{HNO}_{3}$ containing particles where the NAT particles are assumed to be in equilibrium with gas-phase nitric acid. All the three types of particles - NAT, Ice, and Liquid Aerosols - are considered for the sedimentation. The sedimentation speed of particles is calculated according to Pruppacher and Klett (1997). A constant number density $\left(5.0 \times 10^{-3} \mathrm{~cm}^{-3}\right)$ of NAT particles is considered for the analysis (Waibel et al., 1999).

To capture early ozone depletion in 2002-2003, we started the run from November 1 , 2002 whereas for the year 1999-2000 the model was started in mid-December. Antarctic runs start from May 1st to the end of November.

\section{Main features of Arctic ozone loss in 1999-2000, 2002-2003 and 2001-2002}

\subsection{Polar stratospheric cloud area}

The Arctic polar stratospheric temperature in 1999-2000 and 2002-2003 winters were extremely low as compared to winter temperature in 2001-2002, which led to the extensive 

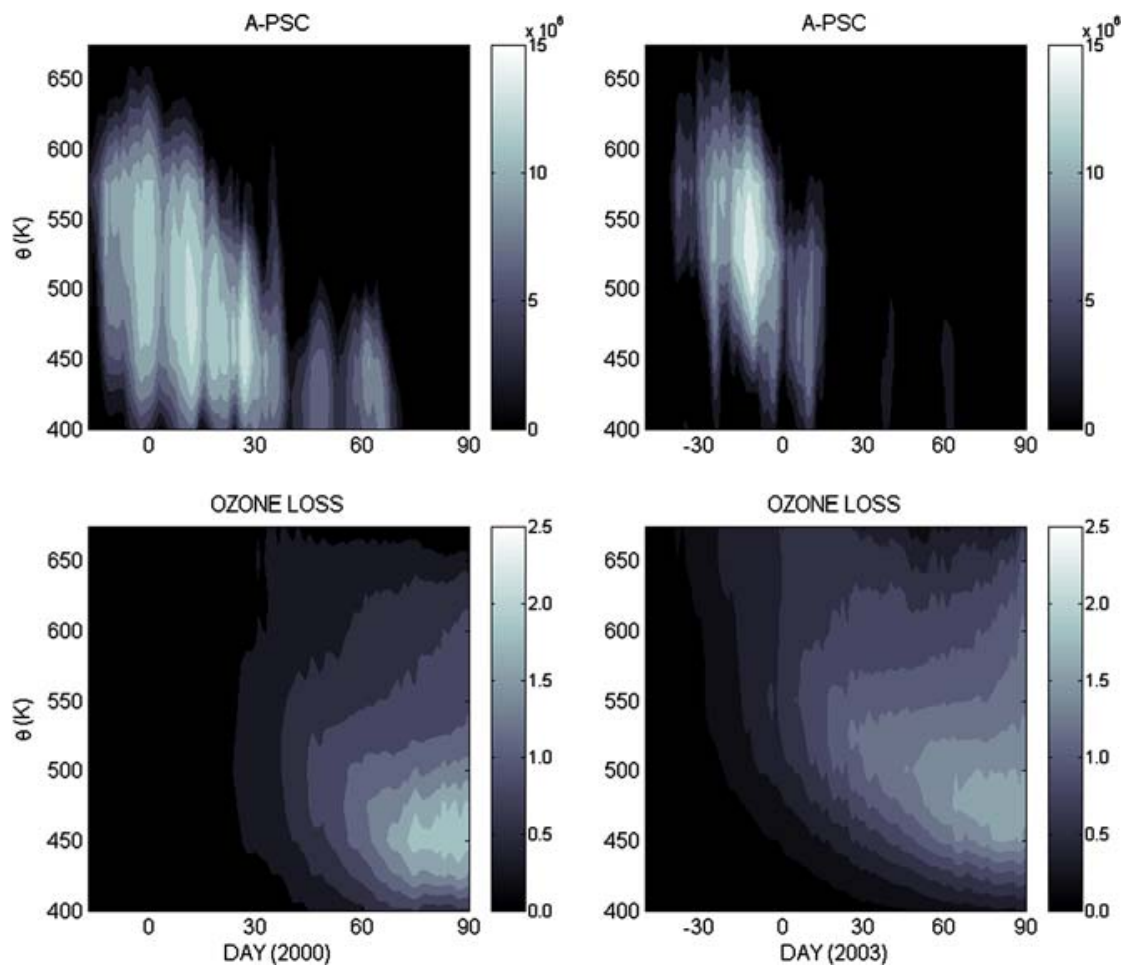

Fig. 1 Upper panel: Geographical area in square kilometres of northern hemisphere with possible existence of polar stratospheric clouds (temperature below the NAT formation temperature $\mathrm{T}_{\mathrm{NAT}}$ ) for 19992000, 2002-2003 Arctic winters. Lower panel: time series of cumulative ozone loss (unit) as a function of potential temperature calculated from MIMOSA-CHIM for the Arctic winter 1999-2000 and 2002 2003

formation of polar stratospheric clouds (PSC). First panel of Figure 1 shows the geographical area $A_{P S C}$ of the stratosphere where PSC are likely to form, for these 2 winters. Note that the figure starts from December 15th in the case of 1999-2000 and November 10th in the case of 2002-2003. APSC is defined as the area characterized by temperatures less than the NAT (Nitric Acid Trihydrate) formation temperature $\mathrm{T}_{\mathrm{NAT}}$, based on the temperature and pressure fields of ECMWF interpolated to the MIMOSA grid. $\mathrm{T}_{\mathrm{NAT}}$ is calculated from the formula of Hansen and Mauersberger (1988). For water vapour partial pressure, a uniform mixing ratio of $4.6 \mathrm{ppmv}$ is assumed. The nitric acid partial pressure is calculated from a nitric acid mixing ratio profile measured by the Limb Infrared Monitor of the Stratosphere (LIMS) (Gille and Russell, 1984).

In both winters, 1999-2000 and 2002-2003, the figure shows that a large stratospheric area characterized by temperature less than $\mathrm{T}_{\mathrm{NAT}}$ existed between 425 and $600 \mathrm{~K}$ potential temperatures. In 1999-2000, low stratospheric temperature leading to the formation of PSC existed from mid-December to mid-February at each level. A low temperature period at the end of February and early March was also observed but the low temperatures were limited to lower levels. In the winter 2002-2003, the temperature was very low from the end of November and beginning of December and a large area prone to the formation of PSC particles existed in early December. The early PSC formation in the Arctic 2002-2003 was $\underline{\text { Springer }}$ 
also observed by the SAGE III instruments (Poole et al., 2003). This cold spell extended up to mid-January.

\subsection{Denitrification}

Denitrification enhances accumulated ozone loss by removing $\mathrm{HNO}_{3}$, which otherwise would deactivate $\mathrm{ClO}$ into reservoir species $\mathrm{ClONO}_{2}$ by releasing $\mathrm{NO}_{2}$ (Salawitch et al., 1993; Waibel et al., 1999). In their paper Gao et al. (2002) have documented the first experimental evidence that denitrification enhances ozone loss. Modeling studies have also shown a significant effect in polar ozone loss due to sedimentation. Tabazadeh et al. (2000) used a box model and showed that the maximum additional ozone loss due to severe denitrification is limited to 30\%. Brasseur et al. (1997) using a 3-D CTM, calculated $20 \%$ more ozone loss due to denitrification in the Antarctic. Due to long period of extremely low temperature, widespread denitrification in the Antarctic polar vortex has been reported in various experimental observations (Santee et al., 1995, 1998; Waibel et al., 1999; Fahey et al., 1989; Brune et al., 1991; Tabazadeh et al., 2000). In the Arctic vortex, which remains much warmer and disturbed than the Antarctic one, the denitrification is not so intense (Hubler et al., 1990; Fahey et al., 1990; Hintsa et al., 1998; Kondo el al., 1999; Dessler et al., 1999; Waibel et al., 1999; Santee et al., 1999, 2000). But in cold winters significant denitrification does occur in the Arctic as well. In the Arctic winter 1999-2000, satellite and in situ measurements of $\mathrm{NO}_{y}$ showed extensive denitrification around $465 \mathrm{~K}$ potential temperature level (Santee et al., 2000, Fahey et al., 2001).

Significant denitrification was simulated by MIMOSA-CHIM between 400 and $600 \mathrm{~K}$ in 1999-2000 and between 450 and $650 \mathrm{~K}$ in 2002-2003. In the former winter, vortex air was found to be denitrified by $67 \%$ in January, $71 \%$ in February and $74 \%$ in March. In the latter winter, the sedimentation of PSC particles started in early December. The vortex air between 475 and $500 \mathrm{~K}$ potential temperature was already denitrified by $68 \%$ at the end of December. Denitrification reduced to 30 and $16 \%$ in February and March respectively. This is in contrast to 1999-2000, when in March the level of denitrification was at its maximum level of $74 \%$. The early December PSC particle growth in 2002/2003 was also observed in SAGE-III instrument (Poole et al., 2003) and is well simulated in our model.

\subsection{Chemical ozone loss}

Cumulative ozone loss in MIMOSA-CHIM is calculated as the difference between simulated ozone and a passive tracer advected by the MIMOSA advection scheme using ECMWF wind fields. At the start of the run, both active and passive ozone are initialized at the same level from the output of the 3D-chemical transport model REPROBUS. The time series of cumulative ozone loss calculated from the model for 1999-2000 and 2002-2003 is shown from 400 to $650 \mathrm{~K}$ in the bottom panels of Figure 1 . From the figure it is clear that the two winters differ considerably in time and levels of the onset of colder spell and consequently in ozone loss. In 1999-2000, the maximum ozone loss was reached between 400 and $475 \mathrm{~K}$ whereas during 2002-2003, it was reached at higher levels. The maximum ozone loss for 1999-2000 at $475 \mathrm{~K}$ was found to be $1.9 \mathrm{ppm}$ and at $450 \mathrm{~K}$ about $2 \mathrm{ppmv}$ at the end of March.

Low temperature in December 2002 triggered very early chlorine activation and consequently early onset of ozone depletion. About $0.3 \mathrm{ppmv}$ of ozone loss is calculated in the first part of December and $0.5 \mathrm{ppmv}$ at the end of December at $475 \mathrm{~K}$ and above. This much of December ozone depletion in the Arctic lower stratosphere is uncommon (Goutail et al., 2005). The centre of ozone loss in 2002-2003 is shifted upward in comparison to 1999-2000, 
and this is in agreement with the location and timing of APSC and chlorine activation. The cumulative ozone loss increases to $0.8 \mathrm{ppmv}$ in January and reaches $1.5 \mathrm{ppmv}$ at $450 \mathrm{~K}$ during March as shown in Figure 1. Singleton et al. (2005) reported a maximum of $1.2 \mathrm{ppmv}$ of ozone loss by March 15 at lower level $(425 \mathrm{~K})$ using 3-D chemical transport model SLIMCAT. It should be noted that during 2002-2003 in MIMOSA-CHIM, the maximum ozone loss occurred at higher level approximately above $450 \mathrm{~K}$.

The 2001-2002 Arctic winter was much warmer than the other two and the ozone loss simulated by the model was small. The cumulative total ozone loss reached only $10 \%$ inside the vortex core at the end of March. This, when compared to both other Arctic winters, indicates the extent of inter-annual variability of Arctic winter/spring stratospheric ozone depletion.

To understand the effect of denitrification on ozone loss in the model, we have compared the ozone loss as a function of equivalent latitude with and without the sedimentation scheme. When the sedimentation scheme was made off for the winter 1999-2000, the maximum ozone loss at $450 \mathrm{~K}$ within the vortex decreased from $70 \%$ to $62 \%$ during this period. At $475 \mathrm{~K}$ also, less ozone loss (50\% as compared to 63\%) was found. This shows that the effect of denitrification was larger at $475 \mathrm{~K}$, where the ozone loss was enhanced by around $23 \%$ as compared to $17 \%$ at $450 \mathrm{~K}$. In terms of mixing ratio, denitrification was found to induce 0.2 to $0.4 \mathrm{ppm}$ extra ozone loss at these levels. The January ozone loss during 2002-2003 inside the polar vortex at $475 \mathrm{~K}$ reached $23 \%$ at the end of the month and $42 \%$ at the end of March. About 29 to $30 \%$ ozone loss was calculated at this level when the sedimentation scheme was made off. At $450 \mathrm{~K}$, similar values were found, so denitrification was found to enhance ozone loss by about 12 to $17 \%$ during that winter.

As for other model studies are concerned, a chemical ozone depletion of up to $60 \%$ was also derived in the $425-450 \mathrm{~K}$ potential temperature range from February 12 to March 20 2000 by Groo $\beta$ et al. (2002) using the Chemical Lagrangian Model (CLaMS). Their model initialization was based on observations from satellite, balloon and ER-2 measurements. Davies et al. (2002) reported 56-74\% ozone loss at $460 \mathrm{~K}$ from the 3-D chemical transport model SLIMCAT by the end of March, however, the model was found to be sensitive to the meteorological fields, giving significantly different ozone losses when forced by two different sets of data UKMO and ECMWF.

\subsection{Effect of model resolution}

In this section, the advantage of using a high model resolution is discussed. The present version with $1^{\circ}$ resolution is a compromise between resolution and reasonable computer time. To test the advantage of a relatively high horizontal resolution, the ozone loss in the 1999-2000 Arctic winter was simulated with one, two and four degree horizontal resolutions. The mean percentage ozone loss as a function of equivalent latitude at $475 \mathrm{~K}$ isentropic level was then compared. Concerning the start of chemical ozone loss in January, the one and two degree resolution does not show much difference. But when the resolution is reduced to four degrees the equivalent-latitudinal belt of ozone depletion region near the vortex edge increases at the cost of slightly decrease in ozone loss. This shows the advantage of running the model at high resolution to capture the ozone loss at the edge of the polar vortex at high solar zenith angle. On January 15 , the maximum ozone loss is $10 \%$ in the case of $1^{\circ}$ resolution and around $8 \%$ in both other cases. The difference between maximum simulated ozone loss increases during the course of the winter: in March, the maximum ozone loss for $1^{\circ}$ resolution reaches $63 \%$, as compared to $59 \%$ and $52 \%$ for $2^{\circ}$ and $4^{\circ}$ resolution respectively. This about $10 \%$ difference in overall ozone loss inside the vortex in March between $1^{\circ}$ and $4^{\circ}$ resolution 
may lead to significant difference when the vortex mean ozone loss or ozone loss rates are computed for comparison with observations. Change in resolution affect the photo-chemistry between the adjacent grid because of difference in solar zenith angle and it also affects the PSC formation and chemistry due to differences in temperature between the adjacent grid points. These differences reflect in ozone loss through the numerical diffusion induced by the regridding process, despite the use of an interpolation scheme designed to minimize this diffusion as described in Section 2. They have to be considered when using chemical scheme within low-resolution climate model to deduce ozone loss.

\section{Simulations of Arctic ozone loss: Comparison with observations}

\subsection{Comparison with ER-2 flight data}

In order to validate the model outputs within the polar vortex, we compared the model results with observations made from the instruments integrated on the ER-2 aircraft during winter 1999-2000. To simulate the ER-2 observations, we adopted a closest approach method. This method consists of capturing the observation in the model simulation by approaching the event spatially and temporarily as close as possible within the limit of the resolution of the model. The coordinate of the location of each measurement, including complete temporal and spatial information, is fed to the run of the MIMOSA-CHIM model. The time resolution of the advection process of the model is one hour but the chemical scheme runs four times in an hour, so results for the concentration of the chemical constituents can be obtained every $15 \mathrm{~min}$. The maximum time difference between measurement and model results can thus not exceed this time interval. As the spatial resolution of MIMOSA-CHIM is $1^{\circ} \times 1^{\circ}$, each measurement can be reached within $0.5^{\circ}$ in latitude and longitude. We calculated the distance between the point of measurement and each grid point of the model at the isentropic level nearest to the measurement level to get the closest point. The value of chemical species at this point is interpolated linearly in vertical direction to reach the level of the measurement. ER-2 flight data are very close in space and time as compared to MIMOSA-CHIM temporal and spatial resolution. That is why fewer model results are obtained in comparison to many ER-2 flight records and some gaps are seen in the plots.

Three flight dates were selected for the comparison (January 20, February 2 and March 7 , 2000 ) when the aircraft flew through the vortex. The comparison for ozone, $\mathrm{ClO}, \mathrm{N}_{2} \mathrm{O}$ (Argus) and $\mathrm{NO}_{y}$ for all these dates are shown in Figure 2. The instrument used to measure ozone was a Dual-Beam UV-Absorption Ozone Photometer (Proffitt and McLaughlin, 1983) with 3\% accuracy and $1.5 \times 10^{10}$ molecules $/ \mathrm{cm}^{3}$ of precision. The $\mathrm{ClO}$ was measured by the technique of chemical conversion, vacuum ultraviolet resonance fluorescence, having the accuracy of $\pm 17 \%$ ( 1 sigma) and a detection limit of 3 pptv (Stimpfle et al., 2004). Argus, a two channel tunable diode laser instrument was used for $\mathrm{N}_{2} \mathrm{O}$ measurements. The precision for $\mathrm{N}_{2} \mathrm{O}$ Argus was estimated to $2.7 \%$ ( 2 sigma) and the accuracy 6.4\% (Hurst et al., 2002, Table 3). The instrument used to measure $\mathrm{NO}_{y}$ has three independent chemiluminescence detectors for simultaneous measurements of $\mathrm{NO}_{y}, \mathrm{NO}_{2}$, and $\mathrm{NO}$ utilising the reaction between $\mathrm{NO}$ in the sample with reagent $\mathrm{O}_{3}$. The estimated accuracy of the $\mathrm{NO}_{y}$ measurement was estimated to $\pm 10 \%$, and the precision ( 1 sigma at $1 \mathrm{~Hz}$ ) to $\pm 40 \mathrm{pptv}$ (Fahey et al., 1989a). The top row of the figure represents the altitude of the flight in terms of potential temperature and the potential vorticity at the location of the measurement. Passive tracers like $\mathrm{N}_{2} \mathrm{O}$ are governed by isentropic transport processes and subsidence. The discrepancy between the modelled and observed $\mathrm{N}_{2} \mathrm{O}$ are found to be due to the cooling rates calculated by the MIDRAD 


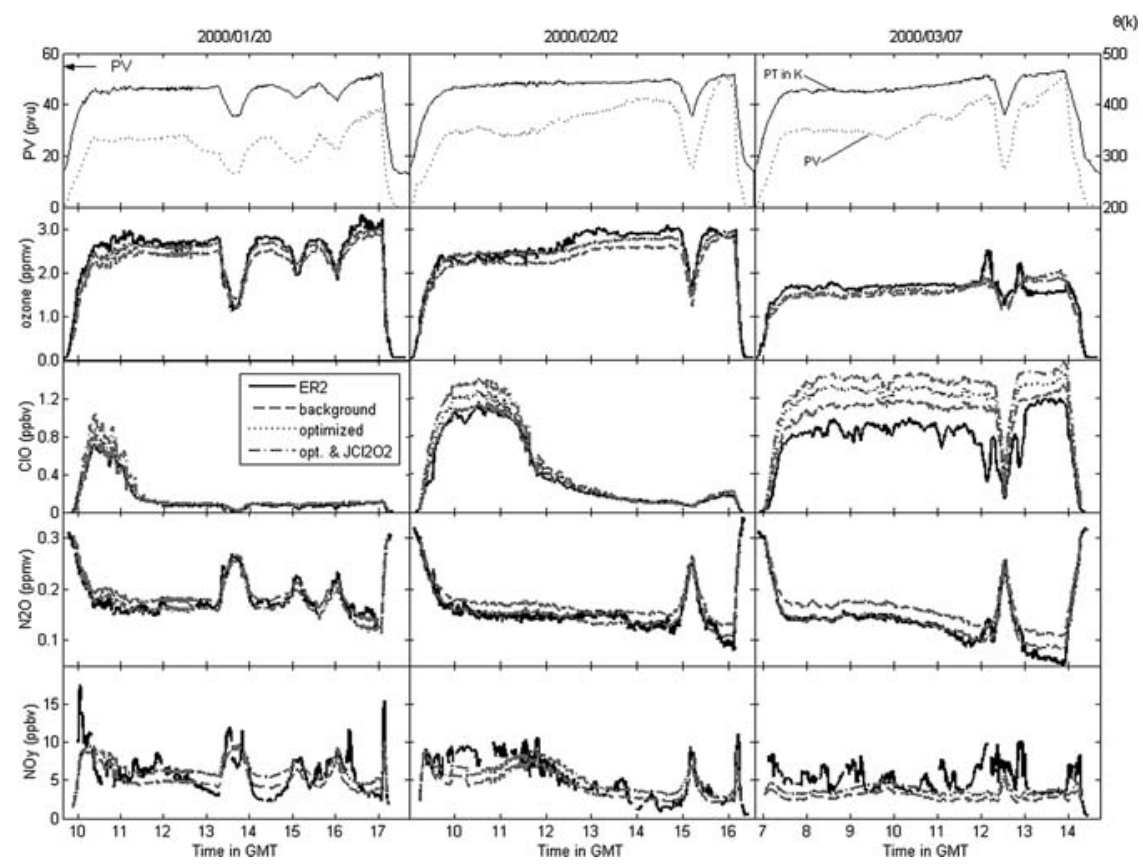

Fig. 2 Time series comparison of MIMOSA-CHIM ozone, $\mathrm{ClO}, \mathrm{N}_{2} \mathrm{O}$, and $\mathrm{NO}_{y}$ with the data from ER-2 flight observations for January 20 (first column), February 2 (second column), and March 7 (third column), in winter 2000 Arctic vortex. Top panel of each column shows the height of the flight in terms of potential temperature and potential vorticity of the point of observation, followed by ozone (in ppmv), $\mathrm{ClO}$ (in ppbv), $\mathrm{N}_{2} \mathrm{O}$ (in ppbv), and $\mathrm{NO}_{y}$ (in ppbv). Three model scenario results were compared against the observations. (i) Background case, particle density as $5 \times 10^{-3} \mathrm{~cm}^{-3}$ (ii) Optimization of heating rates and particle density where the calculated heating rate was increased by $50 \%$ and the particle density was taken as $10 \times 10^{-3} \mathrm{~cm}^{-3}$ (iii) Optimization with "Burkholder $\mathrm{J}_{\mathrm{Cl} 2} \mathrm{O}_{2}$ " values

radiative scheme. By comparing REPROBUS $\mathrm{N}_{2} \mathrm{O}$ fields with the MIMOSA-CHIM it is found that this discrepancy is not due to initialisation. In order to test the ability of the model to simulate correctly the chlorine activation and chemical ozone loss within the vortex, we attempted to obtain the best agreement with observed $\mathrm{N}_{2} \mathrm{O}$ in order to avoid discrepancies due to underestimation or overestimation of subsidence processes. It was found that when cooling rates were uniformly increased by $50 \%$, the modelled and observed $\mathrm{N}_{2} \mathrm{O}$ were in better agreement for all the flights. Depending on the location, the corresponding changes in the heating/cooling rates vary from 0.15 to $0.25 \mathrm{~K}$ per day and it decreases overall $\mathrm{N}_{2} \mathrm{O}$ by about $20 \mathrm{ppbv}$ around $450 \mathrm{~K} . \mathrm{N}_{2} \mathrm{O}$ varies almost linearly with potential temperature in the $400-480 \mathrm{~K}$ region as shown in Figure 2 of Greenblatt et al. (2002). The 20 ppbv change in $\mathrm{N}_{2} \mathrm{O}$ is equivalent to about $10 \mathrm{~K}$ in potential temperature. Tests showed that increasing heating rates did not play any significant role in $\mathrm{NO}_{y}$ distribution. Sensitivity tests were also made by changing the prescribed particle density for NAT particles in the REPROBUS chemical scheme in order to optimize the comparison with $\mathrm{NO}_{y}$ measurements. A doubling of the NAT particle density leads to a significant increase in $\mathrm{NO}_{y}$ i.e. less denitrification. It was then found that a particle number density of $10^{-2} \mathrm{~cm}^{-3}\left(5 \times 10^{-3}\right.$ in background run) along with $50 \%$ increase of heating rate was the best combination to simulate observed $\mathrm{NO}_{y}$ and $\mathrm{N}_{2} \mathrm{O}$. This combination is called optimum model condition. Finally, simulations were made with the photodissociation coefficient of $\mathrm{Cl}_{2} \mathrm{O}_{2}\left(\mathrm{~J}_{\mathrm{Cl2} 2}\right)$ computed from the absorption 
cross-section of Burkholder et al. 1990, in order to assess in our simulation the recent work of Stimpfle et al. (2003). In this article, the authors showed that the use of the reaction rate for the production of $\mathrm{Cl}_{2} \mathrm{O}_{2}$ recommended by JPL (2003) is consistent with observations only if $\mathrm{J}_{\mathrm{Cl}_{2} \mathrm{O}_{2}}$ is calculated with absorption cross sections larger than those recommended by JPL, as those measured by Burkholder et al. 1990. Such simulations along with optimised heating rates and particle density are labelled "Burkholder $\mathrm{J}_{\mathrm{Cl}_{2} \mathrm{O}_{2}}$ " while simulations without any changes are called background simulations.

Model ozone with the optimum scenario is found to be in better agreement with ER-2 flight data for January 20 and February 2, 2000. Out of both changes in the model scenario - heating rates and particle number density - the change in heating rates has the largest impact on ozone loss through the amount of subsided $\mathrm{ClO}_{x}$. The use of "Burkholder $\mathrm{J}_{\mathrm{Cl}_{2} \mathrm{O}_{2}}$ " does not induce much difference on ozone (overlapping of curves). At the same time active chlorine increased on these dates and "Burkholder $\mathrm{J}_{\mathrm{Cl}_{2} \mathrm{O}_{2}}$ " enhances it further. The fact that more $\mathrm{NO}_{y}$ gives more $\mathrm{NO}_{x}$ and consequently less $\mathrm{ClO}$, may explain the overestimation of $\mathrm{ClO}$ on February 2 and March 7 because we have less $\mathrm{NO}_{y}$ on these dates. Concerning $\mathrm{ClO}$, optimum and "Burkholder $\mathrm{J}_{\mathrm{Cl}_{2} \mathrm{O}_{2}}$ " simulation tend to enhance active chlorine. It is clear that the optimum scenario increases chlorine activation all along January through March. Up to the end of January (high solar zenith angle) the "Burkholder $\mathrm{J}_{\mathrm{Cl}_{2} \mathrm{O}_{2}}$ " enhances it further but after that it ceases to affect chlorine activation. To better understand some minor discrepancies we must also consider the corresponding vertical location of the aircraft, since the model data were linearly interpolated as a function of potential temperature. Some deviations in the plots may be attributed to this effect. However, the generally good agreement of the model results with ER-2 observations shows that MIMOSA-CHIM is able to reproduce quantitatively ozone mixing ratio and related species in the Arctic polar vortex, at least in the lower stratosphere.

\subsection{Comparison with the EUPLEX data set}

Measurements of gas-phase composition of Arctic polar stratospheric air have been made during Arctic winter 2003 from dedicated flights of a unique high-altitude aircraft (M55Geophysica) equipped with a comprehensive set of in-situ instruments under the framework of European project EUPLEX. For the comparison with MIMOSA-CHIM simulations, we used the same method of data sampling as for the comparison with ER-2 data sets. The results of the comparison for ozone, $\mathrm{ClO}, \mathrm{N}_{2} \mathrm{O}$ and $\mathrm{NO}_{y}$ on three dates (January 15, January 23, and February 6, 2003) are displayed in Figure 3. Ozone measurements are from the FOX instrument which is a UV absorption photometer. The accuracy is of the order of $5 \%$. $\mathrm{ClO}$ was measured by the HALOX instrument, using the Chemical Conversion Resonance Fluorescence technique (von Hobe et al., 2005). Precision and accuracy of the $\mathrm{N}_{2} \mathrm{O}$ measurements vary from flight to flight but generally the accuracy is somewhat better than $20 \%$ and precision is close to $10 \% . \mathrm{N}_{2} \mathrm{O}$ was measured by HAGAR (High Altitude Gas AnalyzeR) by gas chromatography (Volk et al., 2006). The precision of $\mathrm{N}_{2} \mathrm{O}$ measurements varies from flight to flight (up to $4 \mathrm{ppb}$, see Volk et al., 2006) and the absolute accuracy for the flights is between 1 to $2 \%$. The $\mathrm{NO}_{y}$ instrument consists of a catalytic converter to reduce higher nitrogen oxides to NO and NO is then detected by using the NO-O3 chemiluminescence technique (Voigt et al., 2004). The accuracy is estimated to $15 \%$. All the model scenario results discussed in the previous paragraph are shown in the Figure. The optimum scenario corresponds to the same uniform increase of 50\% of the cooling rates and as in 1999-2000 and optimised $\mathrm{N}_{2} \mathrm{O}$ are in better agreement with observed data. The various scenarios have rather small effect on the ozone fields except on January 15 when the background simulation gives a better agreement with observations. In other cases, the agreement between simulated 


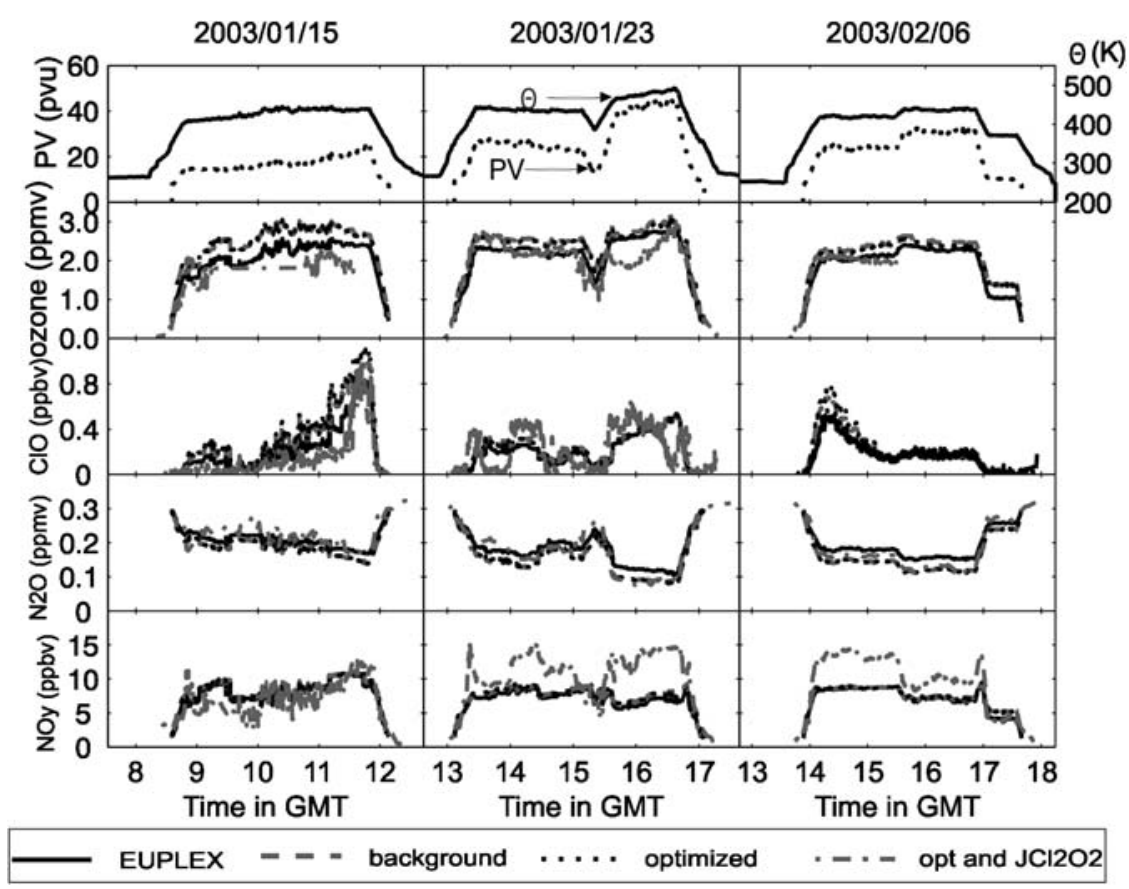

Fig. 3 Time series comparison of MIMOSA-CHIM ozone and ClO mixing ratios, with data from M55Geophysica flights (EUPLEX) observations for January 15 (first column), January 23 (second column) and February 6 (third column) in the Arctic winter 2003. Top panel of each column shows the height of the flight in terms of potential temperature and potential vorticity of the point of measurement, followed by ozone mixing ratio (in ppmv), $\mathrm{ClO}$ mixing ratio (in ppbv), $\mathrm{N}_{2} \mathrm{O}$ mixing ratio (in ppbv) and $\mathrm{NO}_{y}$ mixing ratio (in ppbv)

and observed ozone amounts is good, except on the second leg of the flight performed on January 23 where the simulated ozone values are overestimated for all the scenarios. As in 1999-2000, ClO activation is generally more pronounced in the optimisation scenarios as compared to the background case. On January 15 and February 6, the maximum observed $\mathrm{ClO}$ levels are between the optimum and background cases. Similarly to the 1999-2000 Arctic winter, the simulation with the "Burkholder $\mathrm{J}_{\mathrm{Cl}_{2} \mathrm{O}_{2}}$ " photodissociation coefficient results in a small overestimation of $\mathrm{ClO}$ amount. Concerning $\mathrm{NO}_{y}$, the optimisation results, as expected, in a general increase of the $\mathrm{NO}_{y}$ values. However, despite this increase, simulated $\mathrm{NO}_{y}$ values still underestimate the observed ones, except on January 15, which shows that the parameters to be chosen in the NAT formation scheme can vary from one winter to the next.

\subsection{Comparison with ozonesonde data}

Model results were also compared to ozonesonde measurements at the Ny-Ålesund station $\left(78.5^{\circ} \mathrm{N}-11.8^{\circ} \mathrm{E}\right)$ for the Arctic winters $1999-2000$ and 2002-2003. The comparisons were performed at the $450 \mathrm{~K}$ isentropic level. Figure 4 shows the time series of the modelled ozone mixing ratio over this station together with the observed ozone values from ozonesonde measurements. Model calculations for 1999-2000 show cumulative ozone loss similar to the experimental observations particularly after mid-February. Here also the different model 国 Springer 

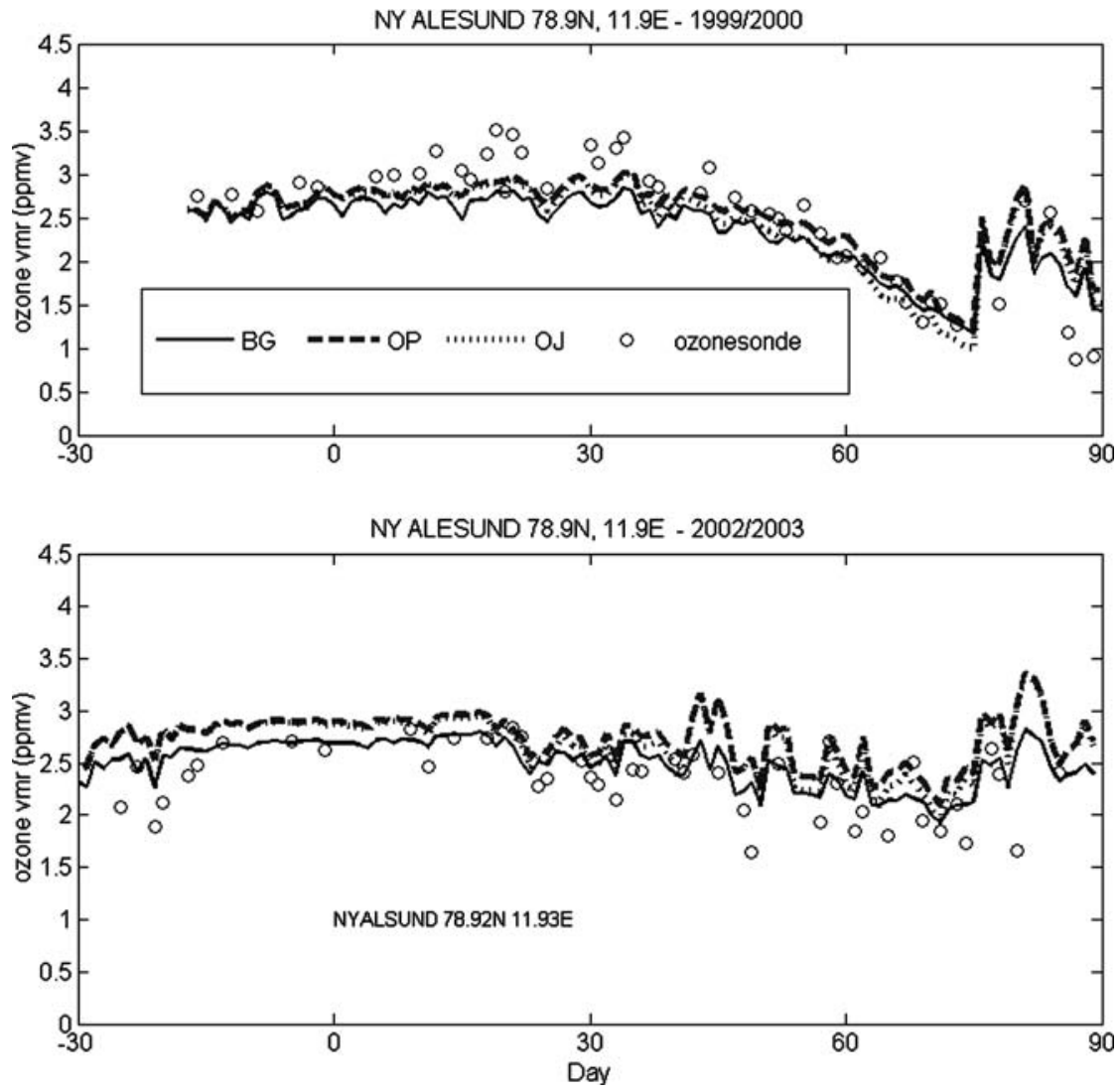

Fig. 4 Comparison of model ozone values (line curves for different model scenario) with observations from ozonesondes (circles) at $450 \mathrm{~K}$ isentropic level for the Arctic station Ny-Ålesund during the Arctic winter $1999 / 2000$ and 2002/2003. Along with given is the geographical locations and name of the stations. BG: Background run, OP: Optimized run, OJ: Optimized run with Burkholder $\mathrm{J}_{\mathrm{Cl}_{2} \mathrm{O}_{2}}$

scenarios described in Section 4.1 are displayed. The figure shows that for the winter 1999-

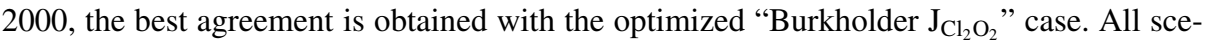
narios underestimate the ozone increase due to the subsidence but the ozone decrease in March is well simulated. In 2002-2003, the optimized scenarios overestimate the observed ozone values in contrast to the winter 1999-2000. The effect of subsidence on ozone is also weaker during this winter. The best agreement between simulated and observed ozone values is obtained for this winter with the background scenario. The measurements show that the ozone destruction was much weaker during this winter than in 1999-2000. Besides, the difference between optimized " $\mathrm{JPL} \mathrm{J}_{\mathrm{Cl}_{2} \mathrm{O}_{2}}$ " and optimized new $\mathrm{J}_{\mathrm{Cl} 2 \mathrm{O} 2}$ scenarios is very small. The difference between these scenarios and the background case is dominated by the adjustment of the heating rates.

\subsection{Integrated ozone loss}

The structure and strength of polar vortex is different at different isentropic levels. To evaluate the integrated column ozone inside the vortex, we calculated the column ozone between 
Table 1 Integrated ozone loss between December 15 and end of the March in different model scenario

\begin{tabular}{|c|c|c|c|c|c|}
\hline \multirow{2}{*}{$\frac{\text { Arctic winters }}{\text { Model scenarios }}$} & & \multicolumn{2}{|c|}{ 1999-2000 } & \multicolumn{2}{|c|}{ 2002-2003 } \\
\hline & & DU & $\%$ & DU & $\%$ \\
\hline \multirow[t]{2}{*}{ Background } & $(350-950 \mathrm{~K})$ & 70.43 & 18.78 & 59.04 & 10.38 \\
\hline & $(400-550 \mathrm{~K})$ & 62.40 & 33.02 & 51.78 & 22.17 \\
\hline \multirow[t]{2}{*}{ Burkholder $\mathrm{J}_{\mathrm{Cl}_{2} \mathrm{O}_{2}}$} & $(350-950 \mathrm{~K})$ & 75.89 & 20.20 & 61.67 & 10.94 \\
\hline & $(400-550 \mathrm{~K})$ & 66.42 & 35.05 & 54.07 & 23.16 \\
\hline \multirow[t]{2}{*}{ Optimum } & $(350-950 \mathrm{~K})$ & 81.07 & 19.50 & 74.64 & 11.04 \\
\hline & $(400-550 \mathrm{~K})$ & 69.17 & 32.54 & 60.04 & 21.02 \\
\hline \multirow[t]{2}{*}{ Opt. with Burkholder J } & $(350-950 \mathrm{~K})$ & 88.55 & 21.23 & 78.55 & 11.73 \\
\hline & $(400-550 \mathrm{~K})$ & 74.00 & 34.68 & 62.73 & 21.95 \\
\hline
\end{tabular}

$68^{\circ}$ and $88^{\circ}$ of northern geographical latitude, in order to select ozone values approximately always inside the vortex. The column ozone loss was computed for the Arctic winters 19992000 and 2002-2003. The different model scenarios, as discussed in Section 4.1, were used and the results are shown in Table 1. The table displays also partial column ozone loss between 400 and $550 \mathrm{~K}$ isentropic level, the region where maximum chemical ozone loss generally takes place. The column ozone loss is given both in percentage as well as in DU. Column ozone loss in percent during 1999-2000 is approximately two times that of the loss during 2002-2003, while the difference in absolute ozone loss is smaller. The striking difference between the two Arctic winters is that the mean transported column ozone (ozone tracer without chemistry) at the end of March 2002-2003 was more than 500 DU (between 500 to 515 DU from March 25 and March 31) whereas in 1999-2000 it was only between 375 to $\sim 390$ DU during the same period. Total ozone measured by TOMS in January 2003 also shows values larger than 500 DU in the Arctic region. The discrepancy between both winters is due to the difference in the strength of the polar vortex during these two years and consequently the ozone transport towards the polar region in the winter/spring season. The 2002-2003 polar vortex was weaker in comparison to 1999-2000 and there was more ozone transport. The table shows that the largest ozone losses are obtained with the optimized "Burkholder $\mathrm{J}_{\mathrm{Cl}_{2} \mathrm{O}_{2}}$ " scenarios in both winters. The difference between this scenario and the background one is on the order of 18 DU for both winters, corresponding to $25 \%$ and 30\% additional ozone loss for 1999-2000 and 2002-2003 respectively.

For the Arctic winter 1999/2000, the model column ozone loss of optimization with "Burkholder $\mathrm{J}_{\mathrm{Cl}_{2} \mathrm{O}_{2}}$ " (88.55 DU total and $74 \mathrm{DU}$ partial 400-550 K) is well compared with the result of Rex et al. (2002). They report $88 \pm 13$ DU of ozone loss by $28 \mathrm{March} 2000$ in the range $400-580 \mathrm{~K}$ using the Match technique from ozonesonde observations. The accumulated total ozone loss derived from SAOZ data and REPROBUS inert tracer reached $105 \mathrm{DU}$ from January 2 to March 25, 2000, while that derived from POAM III measurement and REPROBUS was on the order of $80 \mathrm{DU}$ in the range $380 \mathrm{~K}$ to $700 \mathrm{~K}$ (Harris et al., 2002). In their comparison paper Harris et al. (2002) also reported $85 \pm 10$ DU of ozone loss between November 1999 to mid-March with the HALOE tracer correlation approach. For the 2002-2003 Arctic winter Christensen et al. (2005) estimated $68 \pm 7$ Dobson units of ozone loss between 380 and $525 \mathrm{~K}$ from 10 December 2002 to 10 March 2003, which is very close to our calculation between 400 and $550 \mathrm{~K}(\sim 63 \mathrm{DU})$ with both optimized model scenarios. 

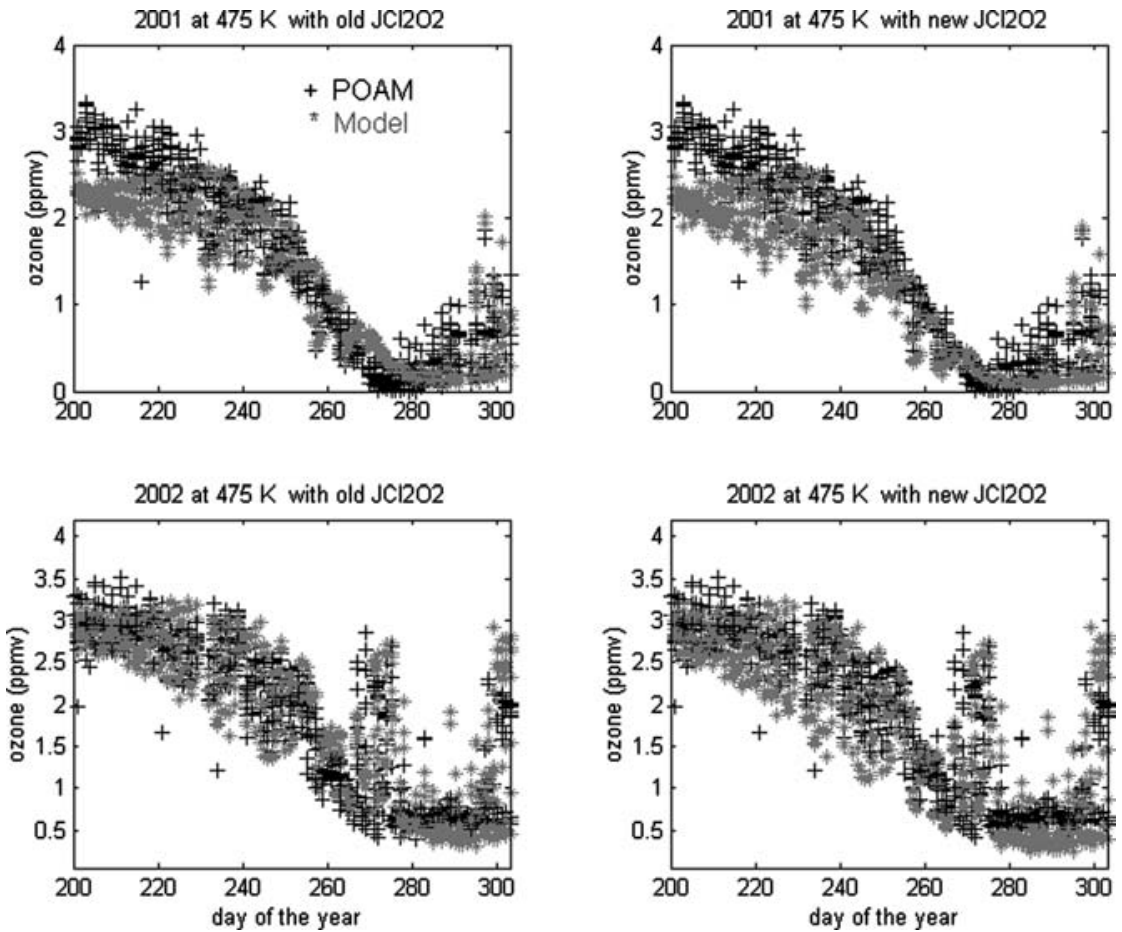

Fig. 5 Ozone mixing ratio evolution at $475 \mathrm{~K}$ in winters 2001 and 2002 as measured by the POAM III

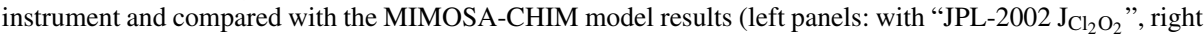
panels: with "Burkholder $\mathrm{J}_{\mathrm{Cl}_{2} \mathrm{O}_{2}}$ " values).

\section{Antarctic simulations and comparison with observations}

For the simulation of the Antarctic polar ozone loss, we concentrated on the winters 2001, 2002 and 2003. Simulated Antarctic ozone levels in 2002 were compared with observations and with the simulation performed in the "normal" Antarctic winter 2001. Although the wave activity and splitting of the polar vortex occurred in the upper stratosphere (above $600 \mathrm{~K}$ ) and the lower levels were less affected, the extra-vortex air mass intrusion was observed at various levels and ozone mixing ratios between 400 and $500 \mathrm{~K}$ were higher in comparison to the other Antarctic winters (Manney et al., 2003; Randall et al., 2003; Konopka et al., 2003). The evolution of the simulated ozone mixing ratio at $475 \mathrm{~K}$ is compared with that of the POAM III observations in Figure 5. POAM III instrument on board the French SPOT 4 satellite was developed by the Naval Research Laboratory (NRL) to measure the vertical distribution of ozone and other parameters using the solar occultation technique. POAM III data are available as a vertical profile of ozone number density in altitude range from $7 \mathrm{~km}$ to $60 \mathrm{~km}$. Each day observations were taken at different locations inside the vortex, providing up to 14 data profiles per day. The model ozone values at $475 \mathrm{~K}$ were interpolated using the latitude and longitude of each POAM III data. Two simulations, with "JPL $\mathrm{J}_{\mathrm{Cl}_{2} \mathrm{O}_{2}}$ " and "Burkholder $\mathrm{J}_{\mathrm{Cl}_{2} \mathrm{O}_{2}}$ " as described in Section 4.1 were made for the comparison. There was no adjustment of the heating rates. The simulations with old and "Burkholder $\mathrm{J}_{\mathrm{Cl}_{2} \mathrm{O}_{2}}$ " are shown in the left and right panels of the figure respectively. The figure shows that the model 

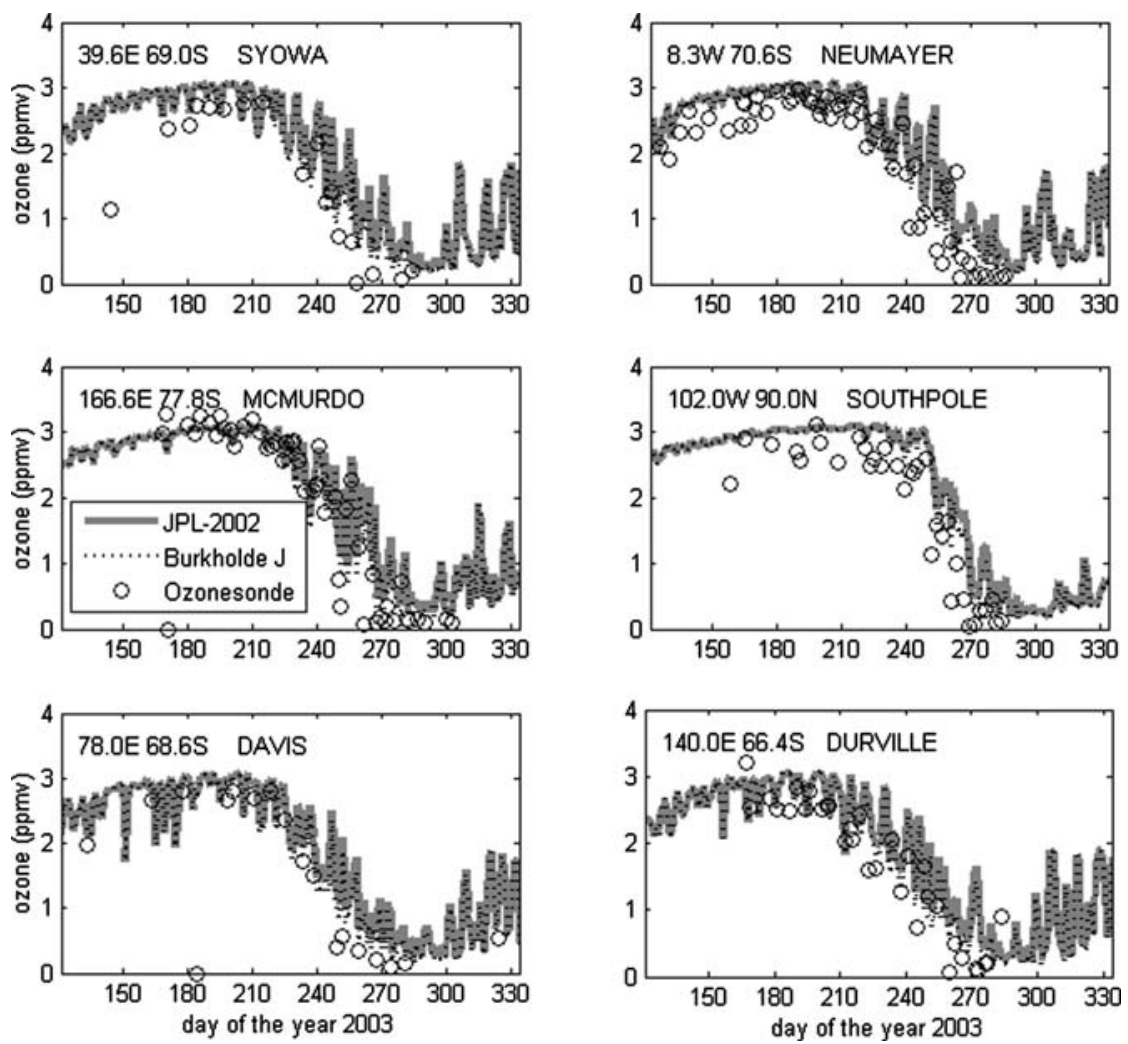

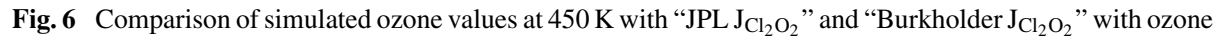
sonde measurements at various Antarctic stations during the winter 2003. Location and names of the stations are given in each panel of the figure

in the beginning of 2001 underestimates the ozone-mixing ratio, which is due to low values in the ozone initialization fields. However, the rapid decrease of ozone during the ozone hole period is rather well simulated for both winters. It is visible in both cases that the use of $\mathrm{Cl}_{2} \mathrm{O}_{2}$ cross-sections from Burkholder et al. (1990) gives a better estimate of the ozone loss rate at the end of the ozone destruction period (from the second half of September up to the beginning of October). This can be explained by the fact that the latitude of POAM III measurements during this period ranges from $80^{\circ} \mathrm{S}$ to $89^{\circ} \mathrm{S}$, so the satellite samples the ozone destruction at rather large solar zenith angle. After the ozone destruction period,

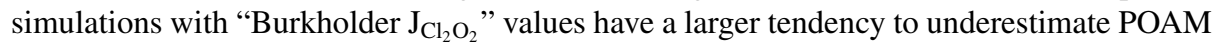
III ozone values, as the satellite moves towards lower latitudes and lower solar zenith angles. The splitting of the ozone hole in 2002 and consequently the abrupt increase in the ozone values are well simulated by the model although some discrepancies with the experimental data can be seen.

Coordinated ozonesonde measurements at various Antarctic stations during the Antarctic winter 2003 were made in the framework of the QUOBI project (Streibel et al., 2004). We selected six Antarctic stations including South Pole for the comparison of the simulation results for that winter. Two simulations with " $\mathrm{JPL} \mathrm{J}_{\mathrm{Cl}_{2} \mathrm{O}_{2}}$ " and "Burkholder $\mathrm{J}_{\mathrm{Cl}_{2} \mathrm{O}_{2}}$ " were performed. The stations are south of 65 degrees latitude and so most of the time during 包 Springer 
the winter/spring season, they are inside the polar vortex. The comparison results for these stations are displayed in Figure 6. It shows that the modelled ozone values are generally in good agreement with the observations, despite a slight overestimation of ozone during the wintertime in some stations like South Pole or Syowa and a general underestimation of the ozone decrease rate at the end of September. The simulations with "Burkholder $\mathrm{J}_{\mathrm{Cl}_{2} \mathrm{O}_{2}}$ " show lower ozone values during that period but still an overestimation as compared to the observations.

\section{Discussion and conclusion}

The 3-D chemical transport model MIMOSA-CHIM was used to simulate the chemical ozone loss in Arctic winters 1999-2000, 2001-2002, and 2002-2003 and Antarctic winters 2001, 2002 and 2003. The Arctic winters 1999-2000 and 2002-2003 were both exceptional with long duration of cold spells in 1999-2000 and early onset of low temperature in 2002-2003. In 1999-2000, a significant ozone loss of around 2 ppmv was found at $450 \mathrm{~K}$ and $1.9 \mathrm{ppmv}$ at $475 \mathrm{~K}$ isentropic levels in March 2000 inside the polar vortex. The denitrification was found to induce about $23 \%$ extra ozone loss during that winter at $475 \mathrm{~K}$. Low temperature and early chlorine activation in 2002-2003 triggered ozone loss from December itself. Early December ozone loss was observed for the first time ever since systematic observations and studies of the Arctic ozone depletion started and this event was well simulated by the model. In 1999-2000, denitrification reached a maximum of $74 \%$ in March as compared to 62\% in January 2003 and 16 to 20 percent in February and March 2003.

In 2002-2003, the ozone depletion started in early December and was at higher levels as compared to the 1999-2000 winter. The maximum ozone loss in the core of the vortex reached around 37-40\% at the end of March. The simulation showed that the effect of denitrification for 2002-2003 was not as pronounced as in 1999-2000, providing 12 to $17 \%$ additional ozone loss.

The simulation results for the winters 1999-2000 and 2002-2003 were compared with $\mathrm{O}_{3}, \mathrm{ClO}, \mathrm{N}_{2} \mathrm{O}$ and $\mathrm{NO}_{y}$ observations made on board the ER-2 and the Geophysica aircrafts respectively, when the aircrafts flew within the vortex. The flight altitude range was generally limited to about $475 \mathrm{~K}$ potential temperature level. The comparisons included several sensitivity tests on the heating rates calculated by the model, the particle number density used in the denitrification scheme and the $\mathrm{Cl}_{2} \mathrm{O}_{2}$ absorption cross-section. Reactive parameters like $\mathrm{ClO}$, ozone and $\mathrm{NO}_{y}$ were compared with observations once the heating rates of the model were adjusted in order to reach the best agreement with observed $\mathrm{N}_{2} \mathrm{O}$ levels. Results showed that the use of the same parameters for the model simulation in both winters had a different effect from one winter to the next. In the first winter, the subsidence adjustment induced a better agreement between simulated and observed ozone values with a slight underestimation but at the expense of an overestimation of $\mathrm{ClO}$, especially in March where the overestimation reaches about $20 \% . \mathrm{NO}_{y}$ levels were better simulated with a particle number density of $10^{-2} \mathrm{~cm}^{-3}$ as compared to $510^{-3} \mathrm{~cm}^{-3}$. In the winter $2002-2003$, the same adjustments induced on the contrary a slight overestimation of ozone along the flight track and a smaller overestimation of $\mathrm{ClO}$ levels as compared to the previous winter. The agreement with observed $\mathrm{NO}_{y}$ levels was not as good especially at the end of January and beginning of February when the simulation underestimated $\mathrm{NO}_{y}$ by about $25 \%$ in some part of the flight tracks. The effect of using Burkholder et al. (1990) $\mathrm{Cl}_{2} \mathrm{O}_{2}$ absorption cross-section was most pronounced at large solar zenith angle, particularly in 1999-2000. Simulated ozone values were also compared to observations from ozone soundings performed over the station of $\mathrm{Ny}$-Ålesund in 
the same winters. The best comparison was obtained in 2002-2003 with the background model scenario while in 1999-2000 observed ozone values were underestimated by the model in January. Yet, a very good agreement on the ozone decrease during February was obtained.

The splitting of the Antarctic polar vortex at the end of September 2002 was well simulated by the model and was compared with POAM III data along with the more usual Antarctic winter 2001. Ozone values from ozonesonde observations performed at six Antarctic stations were found to be in rather good agreement with model ozone values in the 2003 Antarctic winter, despite a small underestimation of the ozone loss rate at the end of the ozone destruction period in the second half of September. A sensitivity test on the $\mathrm{Cl}_{2} \mathrm{O}_{2}$ absorption cross-sections showed that the ozone decrease from mid-August to the end of September is better simulated with the use of Burkholder et al. (1990) absorption cross-sections but at the expense of a somewhat larger underestimation of ozone inside the vortex in October 2002.

These results show the capacity of the MIMOSA-CHIM model to simulate polar ozone loss in the Arctic and in the Antarctic with an accuracy of about 20 to 30\%, depending on the winter. The spatial resolution of $1^{\circ} \times 1^{\circ}$ was found to provide a better evaluation of the ozone loss, particularly at the edge of the polar vortex at high solar zenith angle. Our results are in agreement with other state-of-the-art models and observations but the model requires several improvements particularly on the radiative scheme used to infer diabatic transport across isentropic levels. The heterogeneous chemistry scheme can also be refined in order to take into account the nucleation and growth of polar stratospheric clouds. Improvement of the model representation of chemical and dynamical processes should benefit from the use of data from ENVISAT and other satellite missions like Aura launched in July 2004. Taking into account the present high levels of chlorine and bromine compounds in the stratosphere and the uncertainties on the long-term evolution of the stratosphere in relation with increasing greenhouse gases in the atmosphere, the monitoring of polar ozone loss by validated models and experimental methods will continue to be an important issue.

\section{Annex 1}

\begin{tabular}{|c|c|c|}
\hline $\mathrm{OH}+\mathrm{O}_{3}$ & $\rightarrow$ & $\mathrm{HO}_{2}+\mathrm{O}_{2}(\mathrm{JPL} 2003)$ \\
\hline $\mathrm{HO}_{2}+\mathrm{O}_{3}$ & $\rightarrow$ & $\mathrm{OH}+\mathrm{O}_{2}+\mathrm{O}_{2}($ JPL 2003) \\
\hline $\mathrm{OH}+\mathrm{NO}_{2}+\mathrm{M}$ & $\rightarrow$ & $\mathrm{HNO}_{3}+\mathrm{M}(\mathrm{JPL} 2003)$ \\
\hline $\mathrm{N}_{2} \mathrm{O}_{5}+\mathrm{M}$ & $\rightarrow$ & $\mathrm{NO}_{2}+\mathrm{NO}_{3}+\mathrm{M}(\mathrm{JPL} 2003)$ \\
\hline $\mathrm{CH}_{3} \mathrm{O}_{2}+\mathrm{NO}$ & $\rightarrow$ & $\mathrm{CH}_{3} \mathrm{O}+\mathrm{NO}_{2}($ JPL 2003) \\
\hline $\mathrm{CH}_{2} \mathrm{O}+\mathrm{OH}$ & $\rightarrow$ & $\mathrm{HCO}+\mathrm{H}_{2} \mathrm{O}($ JPL 2003) \\
\hline $\mathrm{HCO}+\mathrm{O}_{2}$ & $\rightarrow$ & $\mathrm{CO}+\mathrm{HO}_{2}(\mathrm{JPL} 2003)$ \\
\hline $\mathrm{CH}_{3} \mathrm{O}_{2}+\mathrm{CH}_{3} \mathrm{O}_{2}$ & $\rightarrow$ & $2 \mathrm{CH}_{3} \mathrm{O}+\mathrm{O}_{2}(\mathrm{JPL} 2003)$ \\
\hline $\mathrm{CLO}+\mathrm{OH}$ & $\rightarrow$ & $\mathrm{HCL}+\mathrm{O}_{2}(\mathrm{JPL} 2003)$ \\
\hline $\mathrm{CLO}+\mathrm{HO}_{2}$ & $\rightarrow$ & $\mathrm{HOCL}+\mathrm{O}_{2}(\mathrm{JPL} 2003)$ \\
\hline $\mathrm{CLO}+\mathrm{CLO}+\mathrm{M}$ & $\rightarrow$ & $\mathrm{CL}_{2} \mathrm{O}_{2}+\mathrm{M}(\mathrm{JPL} 2003)$ \\
\hline $\mathrm{OH}+\mathrm{CH}_{3} \mathrm{CCL}_{3}$ & $\rightarrow$ & $\mathrm{CH}_{2} \mathrm{CCL}_{3}+\mathrm{H}_{2} \mathrm{O}(\mathrm{JPL} 2003)$ \\
\hline $\mathrm{OH}+\mathrm{CH}_{3} \mathrm{CL}$ & $\rightarrow$ & $\mathrm{CH}_{2} \mathrm{CL}+\mathrm{H}_{2} \mathrm{O}($ JPL 2003) \\
\hline $\mathrm{OH}+\mathrm{CH}_{3} \mathrm{Br}$ & $\rightarrow$ & $\mathrm{CH}_{2} \mathrm{Br}+\mathrm{H}_{2} \mathrm{O}$ (JPL 2003) \\
\hline $\mathrm{HO}_{2}+\mathrm{HO}_{2}$ & $\rightarrow$ & $\mathrm{H}_{2} \mathrm{O}_{2}+\mathrm{O}_{2}$ (Christensen et al., 2002) \\
\hline $\begin{array}{l}\mathrm{O}_{1} \mathrm{D}+\mathrm{N}_{2} \\
\underline{\text { Springer }}\end{array}$ & $\rightarrow$ & $\mathrm{O}+\mathrm{N}_{2}$ (Ravishankara et al., 2002) \\
\hline
\end{tabular}


Acknowledgements This work was supported be the European project QUOBI (Quantitative Understanding of polar Ozone loss by Bipolar Investigation). We thank NILU (Norwegian Institute for Air Research) for providing ECMWF data. ozonesonde data, ER-2 flights data and EUPLEX data. We also thanks to P.I.s of Arctic and Antarctic stations (Ny Alesund, Syowa, Neumayer, Mc Murdo, South Pole, Davis, Durville) for providing ozonesonde data, P.I. of POAM III instruments for POAM III data, P.I.s of instruments flew on ER-2 and M55-Geophysica flights for providing ER-2 and EUPLEX mission data, and Ross Salawitch for compiling them into a easy to read merge file and providing them for this work. Parts of the work is also performed when the first author (OPT) was in NASA - Jet Propulsion Laboratory, California Institute of Technology, under National Research Council (NRC) Research Associateship Program.

\section{References}

Allen, D.R., Bevilacqua, R.M., Nedoluha, G.E., Randall, C.R., Manney, G.L.: Unusual stratospheric transport and mixing during the 2002 Antarctic winter. Geophys. Res. Lett. 30(12), 1599, doi:10.1029/2003GL017117 (2003)

Bojkov, R.D., Fioletov, V.E., Balis, D.S., Zerefos, C.S., Kadygrova, T.V., Shalamjansky, A.M.: Further ozone decline during the northern hemisphere winter-spring of 1994-1995 and the new record low ozone. Geophys. Res. Lett. 22, 2729-2732 (1995)

Braathen, G.O., Rummukainen, M., Kyro, E., Schmidt, U., Dahlback, A., Jorgensen, T., Fabian, R., Rudakov, V., Gil, M., Borchers, R.: Temporal development of ozone within the Arctic vortex during the winter of 1991/92. Geophys. Res. Lett. 21, 1407-1410 (1994)

Brasseur, G.P., Tie, X., Rasch, P.J., Lefevre, F.: A three-dimensional simulation of the Antarctic ozone hole: impact of anthropogenic chlorine on the lower stratosphere and upper troposphere. J. Geophys. Res. 02, 8909-8930 (1997)

Brune, W.H., et al.: The potential for ozone depletion in the Arctic polar stratosphere. Science 252, 1260-1266 (1991)

Burkholder, J.B., Orlando, J.J., Howard, C.J.: Ultraviolet absoption cross section of Cl2O2 between 210 and 410 nm. J. Phys. Chem. 94, 687-695 (1990)

Carslaw, K.S., Kettleborough, J.A., Northway, M.J., Davies, S., Gao, R.-S., Fahey, D.W., Baumgardner, D.G., Chipperfield, M.P., Kleinbohl, A.: A vortex-scale simulation of the growth and sedimentation of large nitric acid hydrate particle. J. Geophys. Res. 107(D20), 8300, doi:10.1029/2001JD000467 (2002)

Chipperfield, M.P.: Multiannual simulation with a three-dimensional chemical transport model. J. Gephys. Res. 104, 1781-1806 (1999)

Christensen, T., Knudsen, B.M., Streibel, M., Andersen, S.B., Benesova, A., Braathen, G., Claude, H., Davies, J., De Backer, H., Dier, H., Dorokhov, V., Gerding, M., Gil, M., Henchoz, B., Kelder, H. Kivi, R. Kyrö, E. Litynska, Z., Moore, D., Peters, G., Skrivankova, P., Stübi, R., Turunen, T., Vaughan, G., Viatte, P., Vik, A.F., von der Gathen, P., Zaitcev, I.: vortex-averaged Arctic ozone depletion in the winter 2002/2003. Atmos. Chem. Phys. 5, 131-138 (2005)

Drdla, K., Schoeberl, M.R., Browell, E.V.: Microphysical modelling of the 1999-2000 Arctic winter, 1. Polar stratospheric clouds, denitrification, and dehydration. J. Geophys. Res. 107, 8312, doi:10.1029/2001JD000782[printed 108(D5), 2003] (2003)

Davies, S., et al.: Modeling the effect of denitrification on Arctic ozone depletion during winter 1999/2000. J. Geophys. Res. 107, 8322, doi:10.1029/2001JD000445[printed 108(D5), 2003] (2002)

Dessler, A.E., Wu, J., Santee, M.L., Schoeberl, M.R.: Satellite observations of temporary and irreversible denitrification. J. Geophys. Res., 104, 13,993-14,002 (1999)

Fahey, D.W., et al:: Measurements of nitric oxide and total reactive nitrogen in the Antarctic stratosphere: observations and chemical implications. J. Geophys. Res. 94, 16,665-16,681 (1989)

Fahey, D.W. et al.: In situ measurements of total reactive nitrogen, total water and aerosol in a polar stratospheric cloud in the Antarctic. J. Geophys. Res. 94, 11299-11315 (1989a)

Fahey, D.W., et al.: The detection of large HNO3-containing particles in the winter Arctic stratosphere. Science 291, 1026-1031 (2001)

Fahey, D.W., Solomon, S., Kawa, S.R., Loewenstein, M., Podolske, J.R., Strahan, S.E., Chan, K.R.: A diagnostic for denitrification in the winter polar stratosphere. Nature 345, 698-702 (1990)

Gao, R.S., et al.: Role of $\mathrm{NO}_{y}$ as a diagnostic of small-scale mixing in a denitrified polar vortex. J. Geophys. Res. 107 (D24), 4794, doi:10.1029/2002JD002332 (2002)

Gille, J.C., Russell III, J.M.,: The limb infrared monitor of the stratosphere: experiment description, performance, and results. J. Geophys. Res. 89, 5125-5140 (1984) 
Godin, S., Marchand, M., Hauchecorne, A., Lefevre, F.: Influence of Arctic polar ozone depletion on lower stratospheric ozone amounts at Haute-Provence Observatory $\left(43.92^{\circ} \mathrm{N}, 5.71^{\circ} \mathrm{E}\right)$. J. Geophys. Res. 107(20), 8272, doi:10.1029/2001JD000516 (2002)

Goutail, F., Pommereau, J.P., Lefèvre, F., Van Roozendael, M., Andersen, S.B., Kastad Høiskar, B.A., Dorokhov, V., Kyro, E., Chipperfield, M.P., Feng, W.: Early unusual ozone loss during the Arctic winter 2002/2003 compared to other winters. Atmos. Chem. Phys. 5, 665-677 (2005)

$\operatorname{Groo} \beta$, J.-U., Gunther, G., Konopka, P., Muller, R., McKenna, D.S., Stroh, F., Vogel, B. Engel, A., Muller, M., Hoppel, K., Bevilacqua, R., Richard, E., Webster, C.R., Elkins, J.W., Hurst, D.F., Romashkin, P.A., Baumgardner, D.G.: simulation of ozone depletion in spring 2000 with the Chemical Lagrangian Model of the Stratosphere (CLaMS). J. Geophys. Res. 107(D20), 8295, doi:10.1029/2001JD000456 (2002)

Hansen, G., Svenoe, T., Chipperfield, M.P., Dahlback, A., Hopp, U.-P.: Evidence of substantial ozone depletion in winter 1995/96 over Northern Norway. Geophys. Res. Lett. 24, 799-802 (1997)

Hanson, D., Mauersberger, K.: Laboratory studies of the nitric acid trihydrate: implications for the south polar stratosphere. Geophys. Res. Lett. 15, 855-858 (1988)

Harris, N.R.P., Rex, M., Goutail, F., Knudsen, B.M., Manney, G.L., Muller, R., von der Gathen, P.: Comparison of empirically derived ozone losses in the Arctic vortex. J. Geophys. Res. 107, D20, 10.1029/2001JD000482 (2002)

Hauchecorne, A., Godin, S., Marchand, M., Heese, B., Souprayen, C.: Quantification of the transport of chemical constituents from the polar vortex to middle latitudes in the lower stratosphere using the high-resolution advection model MIMOSA and effective diffusivity. J. Geophys. Res. 107, doi:10.1029/2001JD000491 (2002)

Heese, B., Godin, S., Hauchecorne, A.: Forecast and simulation of stratospheric ozone filaments: a validation of a high-resolution potential vorticity advection model by airborne ozone lidar measurements in winter 1998/1999. J. Geophys. Res. 106(D17), 20,011-20,024 (2001)

Hintsa, E.J., et al.: Dehydration and denitrification in the Arctic polar vortex during the 1995-1996 winter. Geophys. Res. Lett. 25, 501-504 (1998)

Hoppel K., Bevilacqua, R.M., Allen, D.R., Nedoluha, G., Randall, C.E.: POAM III observations of the anomalous 2002 Antarctic ozone hole. Geophys. Res. Lett. 30(7), 1394, doi:10.1029/2003GL016899 (2003)

Hubler, G., Fahey, D.W., Kelly, K.K., Montzka, D.D., Karroll, M.A. Tuck, A.F., Heidt, L.E., Pollock, W.H., Gregory, G.L., Vedder, J.F.: Redistribution of reactive odd nitrogen in the lower Arctic stratosphere. Geophys. Res. Lett. 17, 453-456 (1990)

Hurst, D.F., Schauffler, S.M., Greenblatt, J.B., Jost, H., Herman, R.L., Elkins, J.W., Romashkin, P.A., Atlas, E.L., Donnelly, S.G., Podolske, J.R., Loewenstein, M. Webster, C.R., Flesch, G.J., Scott, D.C.: The construction of a unified, high-resolution nitrous oxide data set for ER-2 flights during SOLVE. J. Geophys. Res. 107 (ND20), 8271 (2002)

Kondo, Y., et al.: $\mathrm{NO}_{y}-\mathrm{N}_{2} \mathrm{O}$ correlation observed inside the Arctic vortex in February 1997: dynamical and chemical effects. J. Geophys. Res. 104, 8215-8224 (1999)

Konopka, P., Groo $\beta$, J.U., Hildegard, M.S., Muller, R.: Mixing and Chemical ozone loss during and after the Antarctic polar vortex major warming in September 2002, J. Atmos. Sci. 62(3), 848859, doi:10.1175/JAS$3329.1(2005)$

Kopp, G., et al.: Evolution of ozone and ozone-related species over Kiruna during the SOLVE/THESEO 2000 campaign retrieved from ground-based millimeter-wave and infrared observations. J. Geophys. Res. 107, 8308, doi:10.1029/2001JD001064,[printed 108 (D5), 2003] (2002)

Lefèvre, F., Figarol, F., Carslaw, K.S., Peter, T.: The 1997 Arctic ozone depletion quantified from threedimensional model simulations. Geophys. Res. Lett. 25, 2425-2428 (1998)

Lefèvre, F., Brasseur, G.P., Folkins, I., Smith, A.K., Simon, P.: Chemistry of the 1991/1992 stratospheric winter: three dimensional model simulation. J. Geophys. Res. 99, 8183-8195 (1994)

Manney, G.L., Sabutis, J.L.: Development of the polar vortex in the 1999-2000 Arctic winter stratosphere. Geophys. Res. Lett. 27, 2589-2592 (2000)

Manney, G.L., Sabutis, J.L., Allen, D.R., Lahoz, W.A., Scaife, A.A., Randall, C.E, Pawson, S., Naujokat, B., Swinbank, R.: Simulations of dynamics and transport during the September 2002 Antarctic major warming. J. Atmos. Sci. 62(3), 690707, doi:10.1175/JAS-3313.1 (2005)

Manney, G.L., Froidevaux, L., Waters, J.W., Santee, M.L., Read, W.G., Flower, D.A., Zarnot, R.F., Zurek, R.W.: Arctic ozone depletion observed by UARS MLS during the 1994-95 winter. Geophys. Res. Lett. 23, 85-88 (1996)

Marchand, M., Godin, S., Hauchecorne, A., Lefevre, F., Bekki, S., Chipperfield, M.: Influence of polar ozone loss on northern mid-latitudes regions estimated by a high-resolution chemistry transport model during winter 1999-2000. J. Geophys. Res. 108(D5), 8326, doi:10.1029/2001JD000906 (2003)

Murray, F.W.: On the computation of saturation vapour pressure. J. Appl. Meterol. 6, 203-204 (1967) 
Newman, P.A., et al:: An overview of the solve/theseo 2000 campaign. J. Geophys. Res. 107(D20), doi:10.1029/2001JD001303 (2002)

Pierce, R.B., et al.: Large-scale chemical evolution of the Arctic vortex during the 1999/2000 winter: HALOE/POAM III Lagrangian photochemical modelling for the SAGE III - ozone loss and validation experiment (SOLVE) campaign. J. Geophys. Res. 107, 8317, doi:10.1029/2001JD001063[printed 108(D5), 2003] (2002)

Poole, L.R., Trepte, C.R., Harvey, V.L., Toon, G.C., Van Valkenburg, R.L.: SAGE III observations of Arctic polar stratospheric clouds - December 2002. Geophys. Res. Lett. 30(23), 2216, doi:10.1029/2003GL018496 (2003)

Proffitt, M.H., McLaughlin, R.J.: Fast-response dual-beam UV absorption ozone photometer suitable for use on stratospheric balloons. Rev. Sci. Instrum. 54, 1719-1728 (1983)

Pruppacher, H.R., Klett, J.D.: Microstructure of atmospheric clouds and precipitations, 2nd ed. Kluwer Academic Publishers (1997)

Randall, C.E., Manney, G.L., Allen, D.R., Bevilacqua, R.M., Hornstein, J., Trepte, C., Lahoz, W., Ajtic, J., Bodeker, G.: Reconstruction and simulation of stratospheric ozone distribution during the 2002 austral winter. J. Atmos. Sci. 62(3), 748764, doi: 10.1175/JAS-3336.1 (2005)

Rex, M., et al.: Chemical depletion of Arctic ozone in winter 1999/2000. J. Geophys. Res. 107(D20), 8276, doi:10.1029/2001JD000533 (2002)

Rex, M., Salawitch, R.J., Santee, M.L., Waters, J.W., Hoppel, K., Bevilacqua, R.: On the unexplained stratospheric ozone losses during cold Arctic Januaries. Geophys. Res. Lett. 30 (1), 1008, doi:10.1029/2002GL016008 (2003)

Rex, M., et al.: A lagrangian approach to separate stratospheric chemical ozone loss from dynamical effects: results for the Arctic winters 91/92 and 94/95. International conference on ozone in the lower stratosphere, Halkidiki, Greece (1995)

Salawitch, R.J., Wofsy, S.C., Gottlieb, E.W., Lait, L.R., Newman, P.A., Schoeberl, M.R., Loewenstein, M., Podolske, J.R., Strahan, S.E., Proffitt, M.H., Webster, C.R., May, R.D., Fahey, D.W., Baumgardner, D., Dye, J.E., Wilson, J.C., Kelly, K.K., Elkins, J.W., Chan, K.R., Anderson, J.G.: Chemical loss of ozone in the Arctic polar vortex in the winter of 1991-1992. Science 261, 1146-1149 (1993)

Santee, M.L., et al.: Interhemispheric differences in polar stratospheric $\mathrm{HNO}_{3}, \mathrm{H}_{2}{ }_{O}, \mathrm{C}_{l} O$ and $\mathrm{O}_{3}$. Science 267, 849-852 (1995)

Santee, M.L., et al.: Six years of UARS microwave limb sounder $\mathrm{HNO}_{3}$ observations: seasonal, interhemispheric, and interannual differences in the lower stratosphere. J. Geophys. Res. 104, 8225-8246 (1999)

Santee, M.L., et al: : UARS microwave limb sounder HNO3 observations: implications for Antarctic polar stratospheric clouds. J. Geophys. Res. 103, 13, 285-13313 (1998)

Santee, M.L., et al.: UARS microwave limb sounder observations of denitrification and ozone loss in the 2000 Arctic late winter. Geophys. Res. Lett. 27, 3213-3216 (2000)

Schiller, C., et al.: Dehydration in the Arctic stratosphere during the SOLVE/THESEO-2000 campaigns. J. Geophys. Res. 107, 10.1029/2001JD000463 (2002)

Schoeberl, M.R., Proffitt, M.H., Kelly, K.K., Lait, L.R., Newman, P.A., Rosenfield, J.E., Loewenstein, M., Podolske, J.R., Strahan, S.E., Chan, K.R.: Stratospheric constituent trends from ER-2 profile data. Geophys, Res. Lett. 17, 469-472 (1990)

Singleton, C.S., Randall, C.E., Chipperfield, M.P., Davies, S., Feng, W., Bevilacqua, R.M., Hoppel, K.W., Fromm, M.D., Manney, G.L., Harvey, V.L.: 2002-2003 Arctic ozone loss deduced from POAM III satellite observations and the SLIMCAT chemical transport model. Atmos. Chem. Phys. 5, 597-609 (2005)

Sinnhuber, B.-M., et al.: Comparison of measurements and model calculations of stratospheric bromine monoxide. J. Geophys. Res. 107(D19), 4398, doi:10.1029/2001JD000940 (2002)

Stimpfle, R.M., Wilmouth, D.M., Salawitch, R.J., Anderson, J.G.: First measurements of $\mathrm{ClOOCl}$ in the stratosphere: the coupling of $\mathrm{ClOOCl}$ and $\mathrm{ClO}$ in the Arctic polar vortex. J. Geophys. Res. 109, D03301, doi:10.1029/2003JD003811 (2004)

Streibel, M., von der Gathen, P., et al.: Ozone loss rates over the Arctic 2002/03 and Antarctic 2003 measured with the Match approach. Proc. Quadrennial Ozone Symposium 55, ed. C. Zerefos, Kos, Greece (2004)

Tabazadeh, A., et al.: Quantifying denitrification and its effect on ozone recovery. Science 288, 1407-1411 (2000)

Voigt, C., Schlager, H., Luo, B.P., Dörnbrack, A. Roiger, A. Stock, P., Curtius, J., Vössing, H., Borrmann, S., Davies, S., Konopka, P., Schiller, C., Shur, G., Peter, T.: Nitric acid trihydrate (NAT) formation at low NAT supersaturations. Atmos. Chem. Phys. Discuss. 4, 8579-8607 (2004)

Volk, C.M., Werner, A., Wetter, T., Ivanova, E., Wollny, A., Ulanovsky, A., Ravegnani, F., Schlager, H., Konopka, P., Toon, G.: Ozone loss within the 2003 Arctic vortex derived from in-situ observations with the Geophysica aircraft. Atmos. Chem. Phys. Discuss. (in preparation) (2006) 
von Hobe, M, Groo $\beta$, J.-U., Muller, R., Hrechanyy, S., Winkler, U., Stroh, F.: A re-evaluation of the $\mathrm{C}_{l} O / \mathrm{Cl}_{2} \mathrm{O}_{2}$ equilibrium constant based on stratospheric in-situ observations. Atmospheric Chem. Phys. 5, 693-702 (2005)

Waibel, A.E., et al.: Arctic ozone loss due to denitrification. Science 283, 2064-2069 (1999)

Wamsley, P.R., et al.: Distribution of halon-1211 in the upper troposphere and lower stratosphere and the 1994 total bromine budget. J. Geophys. Res. 103, 1513-1526 (1998)

Waters, J.W., Froidevaux, L., Read, W.G., Manney, G.L., Elson, L.S., Flower, D.A., Zarnot, R.F., Harwood, R.S.: Stratospheric ClO and ozone from the Microwave Limb Sounder on the Upper Atmosphere Research Satellite. Nature 362, 597-602 (1993)

WMO: Scientific Assessment of Ozone Depletion: 2002, ISBN 92-807-2261-1 (2002) 